\title{
Analisis Upaya Pelayanan Kesehatan di Pusat Pendidikan dan Latihan Olahraga Pelajar (PPLP) Propinsi Sumatera Barat
}

\author{
Pudia M. Indika ${ }^{1}$, Afriwardi $^{2}$, Delmi Sulastri ${ }^{3}$
}

\begin{abstract}
Abstrak
Prestasi Pusat Pendidikan dan Latihan Olahraga Pelajar (PPLP) Sumatera Barat menunjukan ketidakstabilan di tingkat nasional. Siswa yang berobat ke fasilitas kesehatan rata - rata perbulan 50 orang dari 137 orang (36,5\%). Tujuan penelitian adalah menganalisis upaya pelayanan kesehatan olahraga di PPLP Sumatera Barat. Desain penelitian menggunakan pendekatan kualitatif dengan wawancara mendalam dan Focus Group Discussion (FGD). Hasil penelitian didapatkan bahwa upaya pelayanan kesehatan di PPLP Sumatera Barat telah memiliki kebijakan untuk pemeriksaan kesehatan awal calon siswa dan belum terlaksana secara terpusat. Pemantauan kesehatan hanya dilakukan bagi siswa yang mengalami keluhan. Pengobatan dilakukan oleh tenaga tenaga paramedis yang telah ditunjuk. Evaluasi dilakukan oleh Kementerian Pemuda dan Olahraga Republik Indonesia dan hasil evaluasi kesehatan dapat dilihat website sentra keolahragaan.
\end{abstract}

Kata kunci: pelayanan kesehatan olahraga, PPLP

\begin{abstract}
Education and Sport Training Student Centre (ETSC) of West Sumatra performance show instability at the national level. Students of ETSC visited health facility average of 50 of 137 people (36,5\%) monthly. The objective of this study was to analyze the health care effort ETSC sport in West Sumatra. The study design used a qualititave approach with in-depth interviews and a Focus Group Discussion (FGD). The results showed that the health care efforts in ETSC of West Sumatra has had a policy for initial medical examinations of prospective students and have not done centrally. Health monitoring is done only for students who have complaints. Treatment is done by skilled paramedics who have been appointed. Evaluation conducted by the Ministry of Youth and Sports of the Republic of Indonesia and the health evaluation results can be seen websites sports centres.
\end{abstract}

Keywords: health services sports, education and sport training student centre

Affiliasi penulis : 1. Pascasarjana Kesehatan Masyarakat FK UNAND (Fakultas Kedokteran Universitas Andalas Padang), 2. Bagian Fisiologi FK UNAND, 3. Bagian IImu Gizi FK UNAND

Korespondensi : Pudia M. Indika, E-mail : ver_marchi@yahoo.com, Telp: 081213103656

\section{PENDAHULUAN}

Undang-undang Republik Indonesia Nomor 36 tahun 2009 tentang kesehatan menerangkan bahwa untuk mewujudkan derajat kesehatan yang setinggi - tingginya bagi masyarakat, diselenggarakan upaya kesehatan yang terpadu dan menyeluruh dalam bentuk upaya kesehatan perseorangan dan upaya kesehatan masyarakat. Penyelenggaraan upaya kesehatan dilaksanakan salah satunya dengan olahraga. ${ }^{1}$

Olahraga adalah segala kegiatan sistematis untuk mendorong, membina, serta mengembangkan potensi jasmani, rohani, dan sosial. Keolahragaan nasional bertujuan memelihara dan meningkatkan kesehatan dan kebugaran, prestasi, kualitas manusia, menanamkan nilai moral dan akhlak mulia, sportifitas, disiplin, mempererat dan membina persatuan dan kesatuan bangsa, memperkukuh ketahanan nasional, serta mengangkat harkat, martabat dan kehormatan 
bangsa. Olahraga prestasi dilaksanakan melalui proses pembinaan dan pengembangan secara terencana, berjenjang dan berkelanjutan dengan dukungan ilmu pengetahuan dan teknologi keolahragaan. $^{2}$

Proses pembinaan olahraga prestasi yang baik dan benar dilakukan sejak usia dini. Salah satunya adalah Pusat Pendidikan dan Latihan Olahraga Pelajar (PPLP) yang merupakan wadah bagi calon - calon olahragawan untuk mengembangkan bakat olahraganya dengan tidak mengabaikan prestasi akademik. Calon olahragawan yang masuk dan diterima sebagai olahragawan pelajar di PPLP dihasilkan dari seleksi yang ketat, kompetitif dan di peroleh melalui sebuah program yang terencana, teratur dan berkelanjutan. ${ }^{3}$

Keberhasilan pembinaan olahragawan yang sistemik, terpadu, terarah dan terprogram dengan jelas dapat dilihat dari beberapa faktor yang mempengaruhi, salah satunya yaitu kesehatan. Kesehatan merupakan syarat awal dalam pemilihan calon olahragawan dan calon pelatih yang profesional. Kesehatan juga akan berperan dalam pembinaan yang dilaksanakan, dengan cara memantau kesehatan olahragawan secara periodik. Penyelenggaraan kesehatan pada olahraga prestasi sama dengan upaya kesehatan pada umumnya meliputi usaha promotif, preventif, kuratif dan rehabilitatif. ${ }^{4}$

Rusli Lutan mengutip penjelasan Prof. D. Bohmer dari Sportmedical Institute Frankfurt, menjelaskan tiga tugas utama sport medicine adalah pertama mengidentifikasi dan menggambarkan status kesehatan para olahragawan dalam menjalankan aktifitas latihan dan pembinaan jangka panjang, kedua mengidentifikasi dan menggambarkan status fungsi organ tubuh dan kemampuan para olahragawan yang ikut dalam usaha pembinaan olahraga, ketiga mengidentifikasi dan menggambarkan perkembangan fisik para olahragawan dalam pengertian antropometrik sesuai dengan cabang olahraganya. ${ }^{5}$

Petunjuk pelaksanaan dan teknis penyelenggaraan PPLP menerangkan bahwa PPLP memiliki pelaksana harian bidang kesehatan guna bersama dengan pelatih melakukan tes kesehatan secara periodik, memberikan masukan kepada pelatih tentang kondisi siswa untuk keperluan promosi atau degradasi, melayani pemeriksaan kesehatan siswa bila terjadi gangguan atau keluhan kesehatan. Bagi calon anggota PPLP harus mengikuti seleksi yang dilaksanakan instansi terkait salah satunya adalah tes kesehatan. $^{3}$

Peningkatan prestasi ini belum didukung oleh pembinaan yang dilakukan Pusat Pendidikan dan Latihan Olahraga Pelajar (PPLP) sebagai tempat program pembibitan olahraga prestasi sejak dini yang terstruktur dan berkesinambungan. PPLP Sumbar seharusnya dapat mengirimkan siswa-siswa yang telah dibina ke dalam tim olahragawan Sumatera Barat. Pada PON XVII Riau, dari 11 cabang yang terdapat di PPLP Sumbar, hanya mengirimkan 3 orang siswa olahraga sepak takraw, 1 orang olahraga pencak silat dan 1 orang olahraga tinju. Prestasi siswa PPLP Sumatera Barat di tingkat nasional belum baik, bahkan cenderung menurun. Olahraga yang telah lama dibina seperti sepakbola, atletik, sepak takraw, pencak silat dan senam dari tahun ke tahun mengalami kemunduran prestasi. Sebagai tolak ukur prestasi cabang olahraga di PPLP dilihat perolehan medali pada kejuaraan nasional (kejurnas) antar PPLP yang diikuti setiap tahunnya. Dari sebelas cabang olahraga yang dibina di PPLP hanya gulat yang meraih gelar juara umum pada kejurnas antar PPLP seluruh Indonesia tahun $2012 .^{6}$

Hasil wawancara pendahuluan dengan petugas kesehatan PPLP menjelaskan tentang siswa yang sakit dalam satu bulannya rata-rata mencapai 50 orang sampai dengan 60 orang, jumlah siswa yang berobat tetap dan bahkan cenderung meningkat.

Berdasarkan fakta yang telah diuraikan, sehingga perlu dilakukan penelitian untuk mengetahui upaya pelayanan kesehatan olahraga di PPLP Sumatera Barat yang bertempat di Dinas Pemuda dan Olahraga Propinsi Sumatera Barat dan PPLP Sumatera Barat.

\section{METODE}

Penelitian ini menggunakan pendekatan metode kualitatif dengan wawancara mendalam terhadap responden di Dinas Pemuda dan Olahraga Propinsi Sumatera Barat dan Focus Group Discussion (FGD) pada siswa - siswa PPLP. Teknik pemilihan responden yang digunakan dalam penelitian ini adalah 
purposive sampling. Responden penelitian adalah Kepala Dinas, Kepala Bidang Pembudayaan Olahraga, Kepala Seksi Olahraga Dinas Pemuda dan Olahraga Propinsi Sumatera Barat, pengelola PPLP Sumatera Barat, petugas Kesehatan PPLP Sumatera Barat, Dokter Komite Olahraga Nasional Indonesia Sumatera Barat. Pemilihan narasumber FGD dilakukan secara acak dengan simple random sampling.

Data dikumpulkan melalui observasi, dokumentasi dan wawancara mendalam (indepth interview) tentang pemeriksaan kesehatan awal siswa, pemantauan kesehatan secara periodik selama latihan dan evaluasi kesehatan siswa yang meliputi kebijakan, sumber daya manusia dan anggaran dana. Observasi dilakukan melalui pengamatan awal dengan melihat langsung pada PPLP serta telaah dokumen. Langkah mengolah dan menganalisa data adalah membuat transkrip data, reduksi data, penyajian data, penarikan kesimpulan dan verifikasi. Hasil verfikasi di bandingkan dengan telaah dokumen dan ditarik kesimpulan dengan analisis tringulasi. ${ }^{7}$

\section{HASIL}

Data kualitatif didapatkan melalui wawancara mendalam dengan 5 orang informan yang berasal dari Dinas Pemuda dan Olahraga Propinsi Sumatera Barat, 1 orang dari Komite Olahraga Nasional (KONI) Propinsi Sumatera Barat. Focus Group Discussion (FGD) dengan 6 orang siswa dari Pusat Pendidikan dan Latihan olahraga Pelajar (PPLP) Sumatera Barat. Analisis melihat komponen proses yaitu pemeriksaan kesehatan awal calon siswa, pemantauan kesehatan secara periodik selama latihan dan evaluasi kesehatan siswa dengan komponen masukan (input) yaitu kebijakan, sumber daya manusia, dan anggaran dana.

\section{Pemeriksaan Kesehatan Awal Calon Siswa PPLP}

Kebijakan yang ditujukan untuk pemeriksaan kesehatan bagi calon siswa PPLP telah dikeluarkan oleh Kementerian Pemuda dan Olahraga Republik Indonesia (Kemenpora RI) melalui buku Pedoman Penyelenggaran Pusat Pendidikan dan Latihan Olahraga Pelajar Tahun 2012. Kebijakan dari Dinas Pemuda dan Olahraga Propinsi (Dispora) Sumatera Barat sebagai persyaratan mengikuti seleksi administrasi harus memiliki surat keterangan kesehatan yang menyatakan berbadan sehat dari dokter/puskesmas/rumah sakit. Sumber daya manusia yang melakukan pemeriksaan kesehatan bagi calon siswa adalah dokter. Anggaran dana yang dialokasikan untuk pemeriksaan kesehatan awal calon siswa tidak ada, disebabkan oleh tidak adanya perencanaan anggaran. Perencanaan anggaran tidak ada karena belum terbentuknya bidang kesehatan di PPLP sehingga pemeriksaan kesehatan belum dilakukan secara terpusat pada Dispora ataupun PPLP.

\section{Pemantauan Kesehatan Secara Periodik Selama} Periode Latihan

Kebijakan pemantauan kesehatan siswa selama periode latihan secara periodik dalam upaya pelayanan kesehatan telah dikeluarkan oleh Kementerian Pemuda dan Olahraga Republik Indonesia melalui petunjuk teknis penyempurnaan PPLP dari Kementerian Pemuda dan Olahraga Republik Indonesia tahun 2012 yang menjelaskan bahwa pemantauan kesehatan siswa secara periodik dan bekerjasama dengan pelatih. Tidak ada sumber daya manusia dalam pemantauan kesehatan siswa selama periode latihan secara periodik dalam upaya pelayanan kesehatan. Pengobatan terhadap siswa dilakukan oleh bidan yang tidak sesuai dengan kompetensi kesehatan. Tidak adanya perencanaan dalam penyediaan tenaga kesehatan lainnya selain tenaga bidan. Anggaran dana yang dialokasikan untuk pemantauan kesehatan hanya ditujukan pada pengobatan siswa yang berasal dari Anggaran Pendapatan Belanja Negara (APBN) sebesar Rp.1.200.000/bulan yang digunakan untuk pembelian obat - obatan dan Anggaran Pendapatan Belanja Daerah (APBD) sebesar Rp. 500.000/bulan yang digunakan untuk penggantian transportasi tenaga kesehatan.

\section{Evaluasi Kesehatan Siswa}

Kebijakan evaluasi kesehatan siswa telah dikeluarkan oleh Kementerian Pemuda dan Olahraga Republik Indonesia melalui petunjuk teknis penyempurnaan PPLP dari Kementerian Pemuda dan Olahraga Republik Indonesia tahun 2012. Kebijakan 
tingkat daerah untuk evaluasi tidak ada, masih melakukan evaluasi bersama dengan Kemenpora. Sumber daya manusia yang melakukan evaluasi kesehatan terhadap siswa PPLP dilakukan oleh tenaga kesehatan dari Kementerian Pemuda dan Olahraga. Tenaga kesehatan yang terlibat adalah dokter, perawat dan tenaga kesehatan lainnya. Tenaga kesehatan dari PPLP tidak dilibatkan didalam evaluasi yang dilakukan oleh Kemenpora. Anggaran dana yang dialokasikan untuk evaluasi kesehatan siswa tidak ada, disebabkan oleh tidak adanya perencanaan anggaran. Perencanaan anggaran tidak ada karena masih berharap terhadap rangkaian evaluasi yang dilakukan oleh Kementerian Pemuda dan Olahraga.

\section{PEMBAHASAN}

1. Pemeriksaan Kesehatan Awal Calon Siswa PPLP Kebijakan pelaksanaan pemeriksaan kesehatan bagi calon siswa baru didasarkan bahwa PPLP sebagai pusat pembinaan prestasi olahraga memiliki olahragawan yang berusia antara 10 tahun sampai 18 tahun dan termasuk kedalam usia anakanak dan remaja. Pemeriksaan awal bagi calon olahragawan (pra partisipasi) anak-anak merupakan upaya yang sangat penting dalam pencegahan cidera olahraga yang akan timbul selama periode latihan atau kompetisi, dan menghindari komplikasi yang akan memungkinkan untuk timbul penyakit yang telah dideritanya sebelum masuk kedalam latihan. ${ }^{8}$

Pemeriksaan fisik pra partisipasi memiliki tujuan primer sebagai skrining untuk kondisi medis yang dapat mempengaruhi siswa untuk cidera atau sakit selama pelatihan atau kompetisi. Tujuan sekunder pemeriksaan fisik pra partisipasi adalah menentukan kesehatan umum. Pemeriksaan pra partisipasi merupakan pemeriksaan menyeluruh yang meliputi riwayat kesehatan dilakukan sekali pada awal dan ditinjau ulang setiap tahunnya. ${ }^{9}$

Kebijakan kesehatan siswa dapat disusun oleh Pemerintah Daerah seperti yang telah diamanatkan oleh Undang-Undang Nomor 3 tahun 2005 bahwa untuk keselamatan dan kesehatan olahragawan pada tiap penyelenggaraan, penyelenggara wajib menyediakan tenaga medis sesuai dengan teknis penyelenggaraan olahraga prestasi. ${ }^{2}$ Pengembangan kebijakan ini termasuk didalamnya pemeriksaan kesehatan bagi calon siswa PPLP yang diperiksa oleh tenaga medis dari PPLP setempat. Kebijakan dari Dispora adalah pembentukan pelaksana kesehatan di PPLP yang terdiri dari komponen medis, paramedis, dan psikolog.

Pemeriksaan awal untuk orang yang akan berpartisipasi dalam kegiatan olahraga harus melalui serangkaian pemeriksaan yang dilakukan secara sistematis dan menyeluruh yang meliputi proses anamnesis, inspeksi, palpasi, perkusi dan auskultasi. Pemeriksaan ini dapat dilakukan secara individual oleh dokter pribadi, secara massal yang dapat dilakukan dengan melibatkan dokter, pelatih atau profesi lain yang terkait. Materi dalam pemeriksaan diarahkan untuk mengetahui kondisi keseluruhan olahragawan. Secara umum, tujuan akhir adalah menentukan boleh tidaknya olahraga dilakukan oleh olahragawan pada suatu keadaan tertentu. ${ }^{10}$

Dalam buku Penyempurnaan Pedoman Pembentukan Pusat Pendidikan dan Latihan Olahraga Pelajar (PPLP) yang diterbitkan oleh Kementerian Pemuda dan Olahraga tahun 2012 dalam persyaratan dan penentuan anggota PPLP pada poin ke sembilan bahwa anggota PPLP harus mengikuti seleksi yang dilaksanakan oleh instansi terkait (Dinas Pemuda dan Olahraga), diantaranya tes kesehatan. Pemeriksaan kesehatan harus melibatkan tim medis dan paramedis. $^{3}$

Dispora tidak memiliki anggaran dana yang digunakan untuk pemeriksaan kesehatan awal karena belum adanya program yang diajukan untuk pelaksanaannya. Berdasar persyaratan ketika masuk, setiap siswa hanya membawa surat keterangan sehat dari dokter tanpa memiliki formulir yang ditujukan bagi calon olahragawan yang akan berlatih atau berkompetisi.

\section{Pemantauan Kesehatan Secara Periodik Selama Periode Latihan}

Olahragawan yang dibina adalah olahragawan yang berusia anak-anak hingga remaja. Sehingga pemantauan terhadap perubahan anatomi dan fisiologis pada usia tersebut perlu pengawasan agar kemungkinan cidera yang akan timbul dapat diperkecil. Pemantauan dilakukan secara harian, 
bulanan dan tahunan. Untuk perubahan anatomi dan fisiologis dilakukan 4 bulan sekali. Pemantauan kesehatan bukan hanya melakukan pengobatan, tetapi bagaimana dengan kesehatan performa seorang olahragawan menjadi meningkat yang dapat mendukung latihan yang telah diberikan. Pemantauan kesehatan dengan mendahulukan paradigma sehat yaitu mengutamakan upaya promotif dan preventif tanpa mengabaikan upaya kuratif dan rehabilitatif. ${ }^{11}$

Hal yang perlu diperhatikan pada olahraga anak dan remaja adalah supervisi medis yang teratur. Tugas pertama supervisi ini ialah mengeliminasi mereka yang kesehatannya tidak perfect. Anak-anak dengan penyakit kronis dan gangguan pertumbuhan khususnya pada sistem skeletnya, dapat mengikuti kegiatan olahraga rekreasi, tetapi tidak olahraga kompetisi. Olahraga kompetisi hanya untuk mereka yang benar-benar sehat. ${ }^{8}$

Pentingnya pemantauan kesehatan siswa PPLP Sumatera Barat untuk melihat perkembangan kesehatannya. Pemantauan kesehatan secara periodik merupakan kebijakan yang telah disusun oleh kementerian pemuda dan olahraga yang merupakan tanggung jawab Dinas Pemuda dan Olahraga sebagai pelaksana dari kegiatan PPLP. Pemantauan kesehatan dilakukan oleh tenaga medis dibantu oleh tenaga paramedis. ${ }^{3}$ Sehingga perlunya dibentuk bidang kesehatan di PPLP yang akan mengawasi kesehatan siswa. Pemantauan kesehatan melibatkan kerjasama dari medis, paramedis, pelatih dan pengawas olahraga.Pencatatan dan pelaporan siswa yang sakit harus dibuat dengan baik, sehingga pemantauan kepada siswa yang mendapat sakit dapat dicari penyebab masalah kesehatannya. Perencanaan anggaran untuk pemantauan kesehatan dapat dimasukkan dalam Anggaran Pendapatan Belanja Daerah Propinsi Sumatera Barat.

\section{Evaluasi Kesehatan Siswa}

Evaluasi merupakan bagian integral dan tidak dapat dipisahkan dari suatu sistem pembinaan yang mencakup perencanaan, pelaksanaan dan penilaian. Dalam bentuk yang disederhanakan, manajemen pembinaan mencakup ketiga unsur tersebut. Tujuan akhir evaluasi yaitu untuk membuat keputusan berkenaan dengan tindakan perbaikan yang bermanfaat untuk dua hal: (1) menetapkan tindakan untuk memperbaiki atau menyempurnakan kekurangan; dan (2) menetapkan kegiatan untuk mempertahankan hasil yang dinilai "baik" guna meraih kemajuan yang berkelanjutan. ${ }^{12}$

Dalam hal evaluasi yang dilakukan adalah untuk melihat perkembangan daya tahan jantungparu, perkembangan kelentukan dan kekuatan dan dan perkembangan rasio lemak tubuh terhadap berat badan tanpa lemak. Anak yang berolahraga secara teratur akan mempunyai jantung yang lebih besar dan kuat, massa otot yang lebih banyak dan lebih kuat. Jaringan lemak yang lebih sedikit, tulang yang lebih kuat dan sendi yang lebih fleksibel. ${ }^{8}$

Perencanaan untuk mengadakan evaluasi mandiri dari Dispora melibatkan tenaga - tenaga keolahragaan yang berkompeten sesuai dengan keahliannya. Untuk evaluasi kesehatan harus melibatkan dokter dan paramedis yang telah ditunjuk dalam pengorganisasian PPLP. Latihan-latihan yang dikerjakan terutama untuk otot serta ketahanan jantung dan paru, maka dengan sendirinya yang terlihat adalah perubahan-perubahan dalam kedua alat tersebut. ${ }^{13}$

Evaluasi yang dilaksanakan oleh Kemenpora didampingi dengan tenaga medis yang telah ditunjuk dari PPLP.Hasil evaluasi kesehatan menjadi bahan pertimbangan bagi pelatih dan dokter PPLP untuk dapat meningkatkan latihan atau menurunkannya. Anggaran dana yang digunakan dapat diajukan dengan mengadakan kerjasama dengan sarana pelayanan kesehatan terdekat.

\section{KESIMPULAN}

Kebijakan kesehatan olahraga telah dikeluarkan oleh Kementerian Pemuda dan Olahraga Indonesia yang meliputi pemeriksaan kesehatan awal, pemantauan kesehatan secara perodik dan evaluasi kesehatan. Pada PPLP Sumatera Barat belum terbentuk bidang kesehatan yang akan melaksanakan kebijakan. Pelayanan kesehatan masih berorientasi pada pelayanan kuratif dan tidak melibatkan tenaga kesehatan yang berkompeten dalam pelaksanaan pelayanan. PPLP sudah memiliki anggaran kesehatan 
kuratif yang didapatkan dari Anggaran Pendapatan

Belanja Negara (APBN) dan Anggaran Pendapatan

Belanja Daerah (APBD).

\section{DAFTAR PUSTAKA}

1. Undang-Undang Republik Indonesia Nomor 36 Tahun 2009 tentang Kesehatan. Jakarta;13 Oktober 2009.

2. Undang-Undang Republik Indonesia Nomor 3 Tahun 2005 tentang Sistem Keolahragaan Nasional. Jakarta; 23 September 2005.

3. Kementerian Pemuda dan Olahraga. Penyempurnaan pedoman pembentukan pusat pendidikan dan latihan olahraga pelajar (PPLP). Jakarta: Deputi Bidang Pembudayaan Olahraga; 2012.

4. Kementerian Pemuda dan Olahraga. Rencana strategis kementerian pemuda dan olahraga tahun 2010 - 2014.Jakarta: Kemenpora; 2009.

5. Wicaksono D. Sumbangan Sport Medicine. 2010 (diunduh tanggal 06 Juni 2010). Tersedia dari: URL: HYPERLYNK http://blog.uny.ac.id/

6. Dinas Pemuda dan Olahraga Sumatera Barat. Laporan tahunan Dispora Sumatera Barat tahun 2012. Sumatera Barat; 2013.

7. Moleong JL. Metodologi penelitian kualitatif. Edisi Revisi. Bandung: Remaja Rosdakarya; 2012.

8. Giriwijoyo S, Sidik D. Ilmu kesehatan olahraga. Bandung: Remaja Rosdakarya;.2012.

9. Sports Medicine Australia. Safety Guidelines : for children and young people in sport and recreation. Australia: Sports Medicine Australia; 2011.

10. Afriwardi. IImu kedokteran olahraga. Jakarta: EGC; 2011.

11. Klossner D. 2013-14 NCAA : sports medicine handbook. United States of America:NCAA; 2013

12. Hanif AS. Evaluasi terhadap sekolah khusus olahragawan SMP/SMA Ragunan Jakarta. Jakarta: Cakrawala Pendidikan,No.2; 2011.

13. California Intersholastic Federation. sports medicine handbook. California: CIF; 2011. 